\title{
Reaping the Fruits of Contracting out through \\ Governance, Organization and Management: An Empirical Exploration of Local Governing Practices
}

\author{
Eva Sørensen \\ The Roskilde School of Governance \\ Department of Social Sciences and Business \\ Roskilde University \\ Universitetsvej 1 \\ DK-4000 Roskilde, Danmark \\ Jacob Torfing \\ The Roskilde School of Governance \\ Department of Social Sciences and Business \\ Roskilde University \\ Universitetsvej 1 \\ DK-4000 Roskilde, Danmark
}

Received: Aug. 19, 2018 Accepted: Sep. 18, 2018 Online published: Sep. 28, 2018

doi:10.5296/jpag.v8i3.13718～URL: https://doi.org/10.5296/jpag.v8i3.13718

\begin{abstract}
So far, the impact of local governing practices on the likelihood that municipalities will reap the potential fruits of contracting out has only received scant attention. To fill this gap, this article explores the governing practices of local municipalities in order to determine whether or not they match the forms of governance, organization and management that are generally assumed to be conducive to obtaining the desired results of contracting out. Based on a systematic literature review and an explorative empirical case study, we propose a number of conjectures about what seems to work in terms of ensuring positive outcomes from contracting out. The conjectures are compared with the results of a nation-wide survey designed to assess whether or not local municipalities in Denmark are doing what they are
\end{abstract}


supposed to be doing. The empirical analysis shows room for improvement, prompting a discussion of the future prospects for governing contracting out through particular forms of governance, organization and management.

\section{Introduction}

Public regulation and governance serve many purposes and have a long history. Antitrust regulation aims to prevent monopoly pricing, public health regulation seeks to avert epidemics, industrial regulation of workplaces and labor markets protects laborers from exploitation, and environmental and climate governance aims to secure the sustainability of the planet. Regulation and governance is the backbone of mixed economies in which public authorities aim to regulate and govern competitive markets in the pursuit of public goals and values. However, public authorities do not only use regulation and governance to intervene in social and economic life, but may also target the public sector itself. This article explores how public authorities use regulation and governance to reap the fruits of outsourcing that aims to introduce market mechanisms in public service production in order to enhance cost efficiency.

Since the early 1980s, a mixture of fiscal pressures, anti-government ideologies and market-embracing New Public Management reforms has prompted decisions to contract out public services to private contractors that deliver services to government agencies or to private users on behalf of the government, in exchange for money (Kelman, 2002; Amirkhanyan, Kim and Lambright, 2007; Bel and Fageda, 2007). In some countries, public decision-makers have shown considerable interest in how contracting out can improve service quality and spur public innovation (Greve, 2007), but their overriding concern has been to enhance economic efficiency, which is perceived to be low in the public sector due to lack of competition and entrepreneurship (Osborne and Gaebler, 1993). Empirical research on the effects of contracting out on economic efficiency is inconclusive, though systematic reviews reveal a steady decline in the economic gains from contracting out during the period from 2000 to 2015 (Petersen, Hjelmar and Vrangbæk, 2015). Still, there are no indications that uncertainty about the effects will lead to a future decline in public outsourcing. Local governments all over the world are looking for new ways to cut service costs without compromising the quality of public services too much, and contracting out continues to be seen as an attractive tool to attain that goal. The idea that market competition will drive service costs down and perhaps even improve quality - at least in the limited sense of enhanced consumer choice-stimulates local outsourcing in accordance with the neoliberal quest for more market and less state.

The global tsunami of neoliberal New Public Management reforms has prompted a burgeoning body of research on contracting out. Some scholars have sought to explain national, regional and local variations in the prevalence of contracting out by referring to fiscal, political and ideological pressures and differences in administrative culture and capacity (Donahue, 1989; Kettl, 1993; Seidenstat, 1999; Pallesen, 2014). Others have aimed to identify the determinants of public officials' decisions to produce or buy services by looking at the transaction costs of producing and monitoring different kinds of public service 
and analyzing the size and competitiveness of local service markets (Williamson, 1985, 1991; Hefetz and Warner, 2011; Greenwood, 2014). The character, content and effects of contracts made with private providers have also received considerable attention over the years (Domberger and Jensen, 1997; Walls, 2005). Most importantly, numerous researchers have aimed to assess whether the contracting out of public services leads to lower costs without the erosion of service quality. The answer to this pertinent question is highly contested as empirical studies not only reveal different results, but also considerable variations between technical and social services, between countries, and between different points in time (Savas, 1987; Boyne, 1998; Petersen, Hjelmar, Vrangbæk and la Cour, 2011; Petersen, Hjelmar, Vrangbæk and Larsen, 2014; Petersen, Hjelmar and Vrangbæk, 2015). In short, research on public outsourcing has focused on why, when and how to contract out public services as well as on the outcomes in terms of economic efficiency and service quality.

By contrast, researchers have only paid scant attention to the important question of how public authorities govern, organize and manage the process of contracting out public services, and the question of how actual forms of governance, organization and management affect the outcomes of contracting out is hardly ever considered. Hence, as we shall see, only a tiny proportion of the many extant studies of public outsourcing attempts to assess how public governance, organization and management shape the extent to which outsourcing can lower costs and enhance quality. This is surprising, since the outcomes of contracting out are likely to depend heavily on the local forms of governance, organization and management that we refer to in this paper as 'local governing practices'. Local governing practices consist of deliberate attempts by politicians and public managers to govern, organize and manage the complex processes through which public services are contracted out to private contractors, and to monitor and perhaps even improve the outcomes. Governance is defined here as the use of particular policies and regulatory tools such as rules, norms and incentive schemes to shape the conditions for contracting out services before, during and after the contract is signed. Organization is defined as the rule-bound mobilization of the capacities, competences and resources of public organizations in preparing and implementation make-or-buy decisions, including organized attempts to establish a certain division of labor between public and private actors and structure their interaction. Finally, management is defined as the relational practices of public managers that aim to influence the motivation, behavior and communication of public employees, private contractors and end users. While in practice there might be a considerable overlap between governance, organization and management, these are all crucial aspects in efforts to govern the process and outcomes of contracting out. The organizational practices structure, and are structured by, the behavior and interaction of the involved public and private actors. The organizational framework is mobilized and drawn upon when public leaders design and use particular policies and regulatory tools to shape the conditions for action through hands-off governance, and when they aim to influence the behavior of public employees, private contractors and end users through different forms of hands-on management. On the other hand, the attempt to govern and lead contracting out may transform the organizational infrastructure.

The governing of contracting out is scarcely researched and highly undertheorized. While a 
general literature exists on financial contracting (Klein, Crawford and Alchian, 1978), there are few studies of the use of contracts in public service production, and a dearth of studies on the role of organizational practices and management. To boost our knowledge about how public purchasers govern private contract holders, we need to develop a theoretical framework that links governance, organization and management to impact factors such as market creation, coordination, collaboration, monitoring etc. that, at least potentially, may have a positive impact on the outcomes of service contracting. Recently, a few scholars have aimed to sketch out such a framework (Brown, Potoski and Slyke, 2006; Amirkhanyan, Kim and Lambright, 2007; Lindholst, 2009; Lindholst and Bogetoft, 2011), but we need more empirical knowledge about local efforts to govern, organize and manage the process and outcomes of contracting out in order to build a solid foundation for theoretical studies. Exploring the variability and use the local governing practices will tell us what a comprehensive theoretical framework must cover to capture the causal pathways linking the practical efforts of public organizations and managers to outcomes of service contracting.

As a first step in the endeavor to provide a stronger empirical foundation for such theoretical studies, we conducted a nation-wide survey of the governing of service contracting in Danish municipalities. Denmark has one of the most decentralized welfare states in the world. The 98 Danish municipalities spend $70 \%$ of total public expenditure and are responsible for delivering social services, day care, elderly care, primary education, preventive health care and rehabilitation, cultural services, local transport and infrastructure, environmental regulation, etc. In some areas, they even have a statutory right to extend their role and activities. Danish municipalities have their own taxation powers, and their tax revenue is topped up by a block grant from the state. The proportion of all the municipal service tasks that is outsourced to private contractors rose from 22.5 percent in 2007 to 26.3 percent in 2015 (www.noegletal.dk). ${ }^{1}$ The municipalities make their own independent decisions about whether to produce or buy public services. The final decision about whether to outsource a particular service is taken by the mayor and the local councilors, but the municipal directors and contract managers that participated in our survey have considerable influence when it comes to planning and initiating outsourcing and drafting, negotiating, monitoring and sanctioning contracts. While responsibility for these tasks is shared with line managers, the main administrative responsibility for governing, organizing and managing the process of outsourcing public services rests with the municipal directors and contract managers who operate on the basis of a political mandate from the political majority in the city council.

The purpose of our survey is to explore whether Danish municipalities have adopted local governing practices in terms of governance tools, forms of organization and management practices that, at least potentially, may help to secure the desired outcomes of contracting out in terms of lower costs and better quality. In order to determine which governing practices have a positive impact on the outcomes of contracting out, we first conduct a systematic review of existing research (section 2). Based on that, and on an explorative case study of local experiences with governing contracting out in two Danish municipalities, we then

\footnotetext{
${ }^{1}$ The contracting out of public services has also increased in Sweden, although in different areas than in Denmark. Norway has been more hesitant to embrace contracting out than Denmark and Sweden (Petersen and Hjelmar, 2014).
} 
identify a number of governing practices that are likely to help municipalities to ensure positive outcomes from contracting out, defined in terms of cost-efficient solutions that do not reduce service quality (section 3). The prevalence of these governing practices in Danish municipalities will then be analyzed based on the results of the national survey (section 4). The empirical analysis is followed by a discussion of the future prospects for reaping the potential fruits of contracting out (section 5). The conclusion summarizes the argument and points out some avenues for further research (section 6).

\section{Recent Research on the Impact of Local Governing Practices on the Outcomes of Contracting out}

Increasingly, government officials find themselves governing, organizing and managing the contracting out of public services rather than producing and delivering services (Romzek and Johnston, 2005). Therefore, it is important for them to know how to achieve the desired outcomes of service contracting. Unfortunately, research on governing contracting out is scarce. In a systemic review of 6,177 primary studies on contracting out published between 2000 and 2015, we were only able to identify 79 studies that analyze the governance, organization and management of contracting out based on empirical data and valid, transparent methods (see Appendix 1). Of these 79 studies, only 14 aim to assess the conditioning effects of public governance, organization and management on the extent to which contracting out lowers costs and enhances quality. The majority of these 14 studies are qualitative cases studies. Only three are based on survey data. We were surprised by the small number of studies, but this may be explained by the fact that we have not only looked for studies focusing on the governance, organization and management of outsourcing, but also for studies that aim to assess the impact of local governing practices.

Let us briefly review the results from the 14 studies that we discovered through our systematic review by looking at the insights they provide about the impact of governance, organization and management on the outcomes of contracting out. We begin by looking at governance issues, and we then turn to the impact of organization and management.

Public contract managers often face service markets with limited or no competition. A recent study from North America shows that there are less than two bidders on average across 67 public services that have been measured by local public managers in a nation-wide survey (Girth et al., 2012). The question is, then, how public managers handle the lack of competition, and the answer is that they spend a lot of time and energy creating, sustaining and governing service markets. The governance of service markets includes a variety of activities such as segmenting services, attracting private for-profit and non-profit bidders, making public agencies compete with private bidders, retaining a portion of the contracted service in-house to preserve skills and competences, and using intergovernmental contracting as an alternative to competitive contracting involving private firms (Girth et al., 2012).

While the expansion of the scale of markets through inter-municipal collaboration and joint requests for proposals may attract some large for-profit contractors from out of town, it may prevent a lot of small, local for-profit contractors from bidding because they lack the capacity to produce and deliver services on a large scale. In this situation, segmenting, or unbundling, 
public services can be a solution. A comparative case study of bus tendering shows that there are more bidders, more contract renewals and less collusive behavior in London, when the transport network is unbundled so that contractors can bid on one or several bus routes, compared to France, where whole transport networks are contracted out in a big bundle (Amaral, Saussier and Yvrande-Billon, 2009). The different market conditions have a clear and predictable impact on outcomes since the price for contracted bus services in London is falling while it is rising in France. Again, market governance has a clear impact on outcomes.

While the unbundling of public services may help to enhance competition in markets for services with low asset specificity, the new contracting tool known as 'competitive dialogue' may be used in relation to complex services where it is difficult to specify the technical, legal and financial makeup in advance (Lenferink, Tillema and Arts, 2013). Competitive dialogue allows public purchasers to organize a pre-bid public-private dialogue about the public needs and requests and the solutions proposed by potential private bidders. A study of four Dutch infrastructure projects applying the competitive dialogue tool found that it facilitates information exchange, clarifies and modifies public expectations, and stimulates interest and participation in competitive bidding. Competitive dialogue also prevents opportunistic behavior aiming to realize short-term gains to the detriment of long term economic efficiency. The positive impact of dialogue with private contractors is confirmed by other studies that show that the collection of information by contacting potential bidders through formal and informal networks is helpful in enhancing and sustaining competition in service markets (Brown and Potoski, 2004). However, these proactive network activities require considerable investment in managerial capacities for network governance.

Mixed governance models through which the public sector retains part of the contracted service in-house - either because public service organizations win a share of the service production in competition with private bidders or because of a political decision that part of the public service should not be subject to contracting - may not only enhance competition and prevent the formation of private monopolies, but also help to secure a stable service supply by keeping competences in house and to lower the transaction costs of monitoring the private contractors' performance by bench-marking it against the performance of the public provider (Warner and Hefetz, 2008). North American case studies seem to confirm this important finding (Ohemeng and Grant, 2014), whereas case studies from Scandinavia are less conclusive (Petersen and Hjelmar, 2014)

When it is impossible to create a sufficiently competitive service market through different kinds of market governance, intergovernmental contracting might be a good alternative to private contracting. Empirical studies show that intergovernmental contracting is the preferred solution in non-competitive markets because it enables cost reduction through economies of scale in much the same way as for-profit contracting in competitive markets reduces costs through competitive price setting (Girth et al., 2012). Intergovernmental contracting is also used when service production requires coordination across jurisdictions because it lowers the transaction costs.

While more competition helps to discipline private contractors, there can sometimes be too 
much competition, at least seen from the point of view of public purchasers with little knowledge about the market and limited capacity for processing a large amount of proposals. A large number of bidders are costly both to the public purchaser and the private providers, and sometimes the combined transaction costs will be larger than the gains that result from increased competition (Constantino et al, 2012). In these situations, setting up a pre-qualification system that limits the number of bidders by defining a threshold in terms of required experience, competences and capacity is justified. Simulation of a formal model on the basis of empirical data from the contracting out of public maintenance work in Italy shows that reducing the number of actual bidders to an 'optimal number' reduces transaction costs both for the public purchaser and the private providers and thus enhances the total short-term benefits of outsourcing (Constantino et al., 2012).

Turning to the selection of service contractors, Peat and Costley (2001) have explored the institutional conditions for choosing high-performing providers. They studied all the contracts issued in response to a single request for proposals in a North American state and found that the probability of achieving the desired outcomes increases when institutional norms and procedures ensure: 1) that the highest rated proposals are selected; 2) that the contractors are not asked to deliver more services than they propose to deliver; and 3) that there is geographical proximity between the funding agency and the main office of the private contractor. The latter facilitates collaboration, goal alignment and effective monitoring. This finding supports the idea that organizational factors contribute to shaping the outcomes of contracting out.

Management is particularly important in the post-tendering phase. In order to explain the different outcomes in two Swedish cases of service contracting in the water and sewage sector, Mattisson and Thomasson (2007) explored the impact of strategic management after the service contract was signed. In the first municipality, long-term planning was prevented by conflicts between purchaser and provider and the result was reduced service quality. In the other municipality, a positive relationship between purchaser and provider facilitated strategic planning that in turn boosted the quality of the provided services by facilitating coordination and creating synergies. The different outcomes in the two municipalities can be explained by differences in strategic management capacity. Hence, it was only in the latter municipality that the public purchaser had both the organizational competence and resources to manage unforeseen events, cultivate positive working relations and facilitate mutual learning. As such, management and organization interact in affecting outcomes.

A French study based on contract information from 5,000 local governments (Desrieux, Chong and Saussier, 2012), confirms the importance of good, collaborative relations between public purchasers and private providers in the post-tendering phase. Since contracts are always incomplete, purchasers and providers have to deal with non-contractible issues and outcomes through informal interaction and continuous collaboration. Empirical testing of a formal model shows that bundling the public services provided by the same private provider lowers the total price of the provided services without hampering quality. Empirical tests show that this result can neither be explained by economies of scale nor by endogeneity. Rather, the public purchasers seem to develop closer interaction with private providers that 
are responsible for delivering a bundle of services, and the collaborative interaction helps to detect and solve emerging problems and challenges at an early stage.

A study of the introduction of high-powered performance contracts based on large, conditional cash-rewards (sometimes referred to as 'no cure, no-pay' schemes) in the Netherlands in 2002-2005 (Koning and Heinrich, 2013) shows that the pre-program selection effects in terms of parking and creaming were negligible in relation to private contractors' attempts to place unemployed people in jobs, whereas the unintended negative incentive effects were considerable regarding job placement of disabled people. The negative incentive effects of high-powered performance contracts prevailed despite attempts to minimize them by assigning groups of disabled people with more or less the same job prospects to private contractors. On the positive side, however, the introduction of performance contracts enhanced job placements overall, although it was not necessarily those who were most in need of help who got them.

If both dialogue and incentive steering are important, so is the monitoring of contracts. Hence, in imperfect markets where opportunistic behavior is not eliminated by competition, effective contract accountability is paramount to secure desirable outcomes. Effective contract accountability refers to the ability of public funding agencies to design and implement accountability systems that hold service contractors to account for their performance and motivate them to fulfill the contract obligations. Empirical case studies of social service contracting in the state of Kansas found that effective contract accountability is conditioned by a clear specification of responsibilities for reporting, suitable performance measures, easy collection of and access to high-quality performance data, the absence of complex provider networks, and the use of simple and stable reporting technologies (Romzek and Johnston, 2005). Although these findings seem obvious, they are important for public managers to create an effective system for monitoring contract performance and they provide a valuable checklist.

A common thread in studies of the impact of governance and management is the emphasis on the need for organizational capacity building in the public sector. The choice between different market creation tools, the establishment of norms and procedures for selecting the most promising service providers, collaboration and incentive steering in the post-tendering phase, and effective contract monitoring are all tasks that require professional competence and expertise and sufficient resources and capacity. This is confirmed by North American studies showing that local governments in which the administration is run by a professional, non-partisan city manager rather than the mayor are more reluctant to contract out when there is little or no competition and tend to make better use of alternatives to competitive tendering than cities without professional city managers (Hefetz and Warner, 2011).

The studies we have identified through our systematic review provide important insights into the impact of local governing practices on the outcomes of contracting out. The empirical insights are drawn from Western countries that differ in terms of the size and governing capacities of their public sectors and in terms of their political cultures and types of market economy. As such, the results have no general validity, but require further validation through 
comparative studies. Nevertheless, the insights provided by the systematic review enable us to formulate a broad set of research-based conjectures about which governing practices may potentially help to secure the desired outcomes of public outsourcing.

\section{What Can Local Governments Do to Ensure Value-for-Money When Contracting out Services?}

There is an imminent risk that outsourcing will lead to poor and more expensive services due to the lack of competition, opportunistic behavior and the failure to monitor and sanction results. With a view to countering that risk, this section outlines a number of conjectures about what municipal directors and contract managers could do in order to enhance the likelihood that contracting out will lead to positive results in terms of lower costs and improved quality. The conjectures, which structure the presentation of the survey results in the next section, are developed on the basis of our research review. However, to make sure that we have accurately described the local governing practices of Danish municipalities, the insights drawn from the systematic research review are supplemented by insights from an explorative pre-survey study of Danish experiences in this field.

\subsection{Explorative Pre-Survey Study}

In order to explore the range of local governing practices that might influence the outcomes of public outsourcing in Danish municipalities we consulted the national guidelines issued by Udbudsportalen (2011), which is an advisory outsourcing unit within Local Government Denmark (the national association of Danish municipalities). The national guidelines aim to assist local municipalities in governing, organizing and managing contracting out. To get a better understanding of local governing practices, we also conducted qualitative research interviews with six local contracting managers from two Danish municipalities. The contract managers typically had 3-5 years of experience with contracting out. The interviews focused on local experiences with outsourcing, and the contract managers were encouraged to explain how the process of contracting out services had been governed, organized and managed over the past five years. The two municipalities were purposefully selected in order to obtain a considerable variation in local background conditions while avoiding extreme and unrepresentative cases. Hence, three of the public contracting managers came from Roskilde Municipality in which contracting out amounted to 27\% of total service expenditure in 2013 and constituted a highly politicized issue that tends to generate heated debates in the city council. The other three mangers came from Solrød Municipality in which contracting out amounted to $34 \%$ of total service expenditure in 2013 and is not considered to be a politicized issue. The public contract managers drew our attention to the existence of some local guidelines for contracting out that we have also analyzed.

The empirical case studies were not meant to be proper impact studies of local endeavors to govern the contracting out of public services. They were merely explorative studies enabling us to explore local experts' experiences with the use and impact of different governing practices in the past five years. The interviews were based on insights from the research review and recommendations from the national guidelines. Still, they allowed us to capture some local governing practices that we would not otherwise have learned about. 
Without the explorative pre-survey study, we would not have been able to customize the survey to the Danish municipalities, which proved to be important in order to obtain a high response rate. Relying solely on the insights from the systematic research review would have blinded us to the importance of context and prevented us from capturing further aspects of the governing of contracting out.

\subsection{Conjectures about Local Governing Practices that Are Conducive to Desired Outcomes of Outsourcing}

One issue that was not captured by the research review, but which was identified thanks to the pre-study, is the importance of the political focus on, and commitment to, contracting out. Local councilors may translate this focus and commitment into a local policy for contracting out services that specifies the goals, principles and procedures for contracting out services. Political focus and commitment are important because they signal what kind of results administrators should aim to obtain as a result of outsourcing public services, and they may put pressure on administrative staff to deliver. The existence of a local policy for contracting out also provides support to the municipal director and contracting managers who are often delegated considerable competence in the field of contracting out, albeit within the overall policy direction set by the mayor and the city council. Political support and delegation of authority both help to prevent sporadic political interference in concrete cases that may hamper long-term goal attainment. Last but not least, local policies for contracting out often contain references to social and/or environmental clauses that must be observed when outsourcing public services. Such clauses may help to generate support from public employees and local stakeholders, reducing their resistance to the contracting out of services. In sum, the first conjecture is that a local policy for procurement and contracting out endorsed by the Municipal Council is conducive to producing the desired effects of outsourcing in terms of delivering high quality, low cost services.

The next conjecture concerns administrative support for contracting out and the presence of the required organizational competences and capacities for outsourcing public services through a competitive tender. The importance of administrative support, competences and capacities, which can be ensured through the establishment of a particular administrative unit that plans and guides the contracting process in more or less close collaboration with the service-producing line organizations, is well covered in the research literature and is also supported by the national guidelines and the local interviews. The special contracting out unit with the right composition of different skills and competences, with experience from previous processes and with the capacity to assist line organizations in preparing and executing contracting out is of the utmost importance. Hence, the second conjecture suggests that the establishment of a special contracting unit with particular resources and competences within the municipality will increase the likelihood that contracting out will lower costs while improving quality.

The next conjecture focuses on the impact of market creation. Both the research review and the explorative pre-survey study give reason to believe that persistent efforts to ensure sufficient competition between bidders in public quasi-markets is key to reaping the fruits of 
contracting out. The interviews with public contract managers point to three core activities that are pursued in the effort to create competitive service markets. The first is to hold an explorative pre-tendering dialogue with potential bidders and their various organizations in order to assess the number and quality of potential bidders and to learn how competition can be enhanced by adjusting the description and volume of services subject to contracting in order to match the capacities of potential bidders. The second activity is the segmenting or unbundling of public services in order to allow smaller contractors with limited capacity to make a bid. The third activity is to make joint requests for proposals with other municipalities in order to lower the transaction costs for each municipality while increasing the size of the market in order to make it possible for private contractors to benefit from economies of scale. Based on these activities, the third conjecture infers that dialogue with potential bidders and their organizations, the unbundling of public services, and/or joint requests for proposals will enhance competitiveness and increase the likelihood that contracting out will deliver on its promises.

The following conjecture focuses on measures that can reduce transactions costs. We have already seen that joint requests for proposals can have that effect, but the research review also indicated that the use of prequalification and a mixed model that keeps part of the service production in house can lower transaction costs. Whereas pre-qualification should only be used in situations with a large amount of bidders, the mixed model can be used in all circumstances, except those where the utilization of the necessary infrastructure cannot be divided or shared and, therefore, there is only room for one service provider (natural monopolies). Based on this, the fourth conjecture states that prequalification and a mixed model can, under certain conditions, help to reduce transaction costs and thus improve economic efficiency.

As we alluded to above, the case studies conducted in the pre-survey study helped us to uncover a local governing practice that was not flagged in the research review. Apparently, some municipalities ask public service organizations to produce a control bid, or shadow bid as some call it. The control bid allows the evaluators to compare the price and quality of the bids from private contractors with a rough estimate of the costs of keeping the service in-house (this can be gleaned from last year's budget) and of the current level of service quality (this can be estimated on the basis of performance management reports). This comparison enables evaluators to eliminate those bids that are either unrealistic because they claim to be able to produce the same quality service at a much lower price, or which will not produce additional value for money. Having a relatively 'neutral' yardstick when comparing competing proposals and negotiating contracts helps public managers to put pressure on private contractors, while at the same time helping them to avoid market dumping that might lead to supply security problems later on. Hence, the fifth conjecture is that the use of control bids will help to generate value-for-money when contracting out services.

It is hazardous to award a contract to one or more private contractors in a situation where there is a lack of competition, where irregularities and complaints are numerous, and where the bids are poor quality and none of them seems likely to improve cost efficiency without lowering quality. Nevertheless, political-ideological pressures to contract out services, and 
administrative reluctance to accept that many hours of planning and preparation have been wasted, may sometimes persuade contract managers to go through with a contracting process instead of annulling the request for proposals. By contrast, the annulment of a request for proposals can, under particular circumstances, be an important tool for preventing outsourcing from leading to a downwards spiraling of costs and quality, and for ensuring that a public monopoly is not merely replaced with a private one. This observation is embedded in the sixth conjecture, which proposes that annulments of requests for proposal can help to ensure that contracting out generates proper and desirable results.

Since private for-profit contractors are in business to make a profit rather than to produce public value, it is very challenging to motivate them to produce and deliver high quality public services at low costs. One tool that can help to achieve this is to draw up contracts with clear specifications and incentives. The more clearly the contract describes the content and character of the services to be delivered, defines public demands and standards, and specifies the economic resources that are allocated to the task, the less room there is for opportunistic behavior and slacking. While clear specifications are hard to come by in the field of social services, which relies on the human factor, they may be easier to fashion in the field of technical services. In addition, it is thought that the more incentives that are built into the contract to deliver better and cheaper services, the better the outcomes private providers will deliver. Although this presumption is modified by the risk of sub-optimizing, the research review indicated that high-powered performance contracts may work in some areas while not in others. Hence, the seventh conjecture is that the use of contracts that clearly specify tasks and demands and contain clear incentives to enhance performance will help to produce positive outcomes.

Private contractors cannot produce value for money if they do not possess the right resources and competences. Although the importance of adequate resources and competences has been duly noted in the research literature (Romzek and Johnston, 1999), it did not feature prominently in our research review. However, both the national guidelines and our interviews with the local contract managers are clear about the significance of resources, competences and capacities. Several contract managers told us that - contrary to the assumptions of contract management theory - the know-how of private contractors' staff cannot be taken for granted. Consequently, the eighth conjecture asserts that contracts that delineate the professional qualifications and competences that private contractors' employees must possess are likely to enhance economic efficiency and service quality.

The research review emphasizes the role of 'relational contracts' that - contrary to the assumptions of principal-agent theory - oblige private contractors to engage in continuous coordination and collaboration with public purchasers. This not only enhances goal alignment, but also builds trust, which helps to lower the transaction costs of monitoring. The interviews with public contract managers brought up the question of the private contractors' collaboration and dialogue with citizens and users, which is important in enhancing service quality. These collaborative advantages are combined in the ninth conjecture, which states that that contracts which oblige private contractors to participate in an ongoing dialogue with public authorities and end users are likely to lower costs and enhance service quality. 
When competition and goal alignment through ongoing collaboration fail to eliminate opportunistic behavior, the fallback option of public purchasers is contract monitoring through which they can put pressure on private contractors to perform well. Different monitoring techniques can be used provided the public purchasers have the knowledge and skills that are needed. However, it is not enough to know how different monitoring techniques are used. If the majority of administrative resources are tied up in market creation and contract negotiation, contract monitoring will be ineffective. Hence, the tenth conjecture is that the production of value for money through outsourcing depends on the presence of adequate monitoring techniques, the managerial skills to deploy them and interpret the results, and allocation of sufficient administrative resources to contract monitoring.

Although contracting out is based on the idea that competition for markets between private bidders will drive costs and quality up, there is growing concern for how inter-organizational knowledge sharing can improve performance. Hence, public authorities may get better results from contracting out services by sharing knowledge and information with each other, and service innovation may emerge as a result of knowledge sharing between public and private providers in mixed models. Both of these insights found support in our interviews with public contract managers, and they bring us to the last conjecture, which is that managerial orchestration of knowledge sharing will help to lower costs and improve the quality of contracted services.

Most of the above conjectures fall into the category of 'governance' (3, 5, 6, 7, 8 and 9) and only a few are primarily related to either 'organization' (2 and 4) or 'management' (1 and 11). The tenth conjecture seem to cut across the three categories. This distribution is hardly surprising given the pivotal role of regulatory contracts.

\section{Results from A Danish Survey: Are the Municipalities Doing what They Are Supposed to Do?}

As a first step in deepening our understanding of how local governing practices affect the outcomes of contracting out, we conducted a nation-wide survey to obtain a more precise picture of how Danish municipalities are governing contracting out and determine whether or not they are doing the right thing as defined by the conjectures set out in the previous section. In this section, we first briefly describe how we conducted the survey and then we present the results of our exploration of the empirical prevalence of the governing practices stipulated in our eleven conjectures.

\subsection{Survey Report}

To secure a high response rate in our nation-wide survey of local governing practices, we collaborated with the National Association of Municipal Directors (KomDir) which officially endorsed the survey and sent the web-based survey link to the local municipalities. After sending two reminders, we ended up with responses from 63 out of the 98 Danish municipalities ( 59 of the responses were complete and four were almost complete). As such, the response rate was 64\%, which is exceptionally high for this kind of survey. Analysis of the size and geographical location of municipalities that did not participate in the survey 
raised no concerns about the presence of a systematic bias among non-participants.

The survey was administered to the municipal directors, who were instructed to either answer it themselves if they thought they had sufficient knowledge, or delegate responsibility for it to a leading contracting manager or another trusted manager with expert knowledge about local governing practices in the field of contracting out. In $16 \%$ of the municipalities, the director herself answered the on-line survey, while in $43 \%$ it was answered by a leading contracting manager, and in $41 \%$ by another manager. Judging from the number of years they had worked with contracting out, they all seemed rather experienced and thus may be said to be reliable sources of information.

The respondents were asked about the local use of different tools and practices mentioned in the conjectures presented in the previous section. Some of the questions were asked both in relation to social services and technical services because some studies suggest that governing practices are different in these two areas. In a couple of cases the response categories were simply 'yes' or 'no'. However, in most cases the respondents were given the opportunity to locate their answers along a fine-grained continuum. The continuum of response categories ranged either from 'never', 'very rarely', 'rarely', 'sometimes', 'often', 'very often' to 'always'; or from 'not at all', 'very low degree', 'low degree', 'some degree', 'high degree, 'very high degree' to 'fully'. In all cases, the respondents were offered the possibility to say 'I don't know' in order not to force them to provide an invalid answer.

Fine-grained response categories provide rather precise answers, but can be difficult to work with in data analysis. Therefore, we have merged the three most positive and the three most negative response categories and used percentage balances (the three positive response categories minus the three negative ones) in the analysis to facilitate a succinct presentation of the results. The positive and negative poles that result from this merger of response categories provide a parallel to the 'yes' and 'no' responses to questions resulting in dichotomous answers (see table 1 below).

\subsection{Survey Results}

The results from the nation-wide survey that are relevant to the conjectures presented in the previous section are displayed in table 1 .

\begin{tabular}{|c|c|c|c|c|c|}
\hline $\begin{array}{l}\text { Local governing practices that are } \\
\text { considered to be conducive to } \\
\text { enhancing the desired effects of } \\
\text { contracting out: }\end{array}$ & $\begin{array}{c}\text { [no] } \text { or }[\text { never + } \\
\text { very rarely + } \\
\text { rarely] or [not at all } \\
\text { + very low degree + } \\
\text { low degree] } \\
\text { (pct.) }\end{array}$ & $\begin{array}{c}\text { [ - ] or } \\
\text { [sometimes] } \\
\text { or } \\
\text { [some degree] } \\
\\
\text { (pet.) }\end{array}$ & $\begin{array}{c}\text { [yes] or often + } \\
\text { very often }+ \\
\text { always] or [high } \\
\text { degree + very high } \\
\text { degree + fully] } \\
\text { (pct.) }\end{array}$ & $\begin{array}{l}\begin{array}{l}\text { Don't } \\
\text { know }\end{array} \\
\text { (pet.) }\end{array}$ & $\begin{array}{c}\text { Percentage } \\
\text { balance (= } \\
\text { positive - } \\
\text { negative) } \\
\text { (pct.) }\end{array}$ \\
\hline $\begin{array}{l}\text { 1. Has the Municipal Council agreed on a policy } \\
\text { for procurement and contracting out? }\end{array}$ & 17 & - & 78 & 5 & +61 \\
\hline $\begin{array}{l}\text { 2. Has the municipality established an } \\
\text { administrative unit that supports and guides } \\
\text { outsourcing? }\end{array}$ & 3 & - & 97 & 0 & +94 \\
\hline \multicolumn{6}{|l|}{ 3. Focus on market creation } \\
\hline $\begin{array}{l}3.1 \text { How often do you engage in dialogue with } \\
\text { potential bidders in the pre-contracting phase? }\end{array}$ & 0 & 24 & 74 & 3 & +74 \\
\hline
\end{tabular}


3.2 How often do you engage in dialogue with relevant industrial organizations in the pre-contracting phase?

3.3 How often do you use segmenting or unbundling of technical services to recruit further bidders?

3.3 How often do you use segmenting or unbundling of social services to recruit further bidders?

3.4 Does the municipality make joint requests for proposals with other municipalities?

4. Reduction of transaction costs

4.1 How often do you use pre-qualification to reduce the number of bids?

4.2 How often do you keep part of a technical service in house while contracting out another part of the service?

4.3 How often do you keep part of a social service in house while contracting out another part of the service?

5. Is it common for the municipality to use control bids, for example the first time a service is contracted out?

6. Annulment

6.1 How often have you been forced to annul a request for proposals?

6.2 How often does annulment occur due to the poor quality of proposals?

6.3 How often does annulment occur due to lack of competition?

6.4 How often does annulment occur due to irregularities or complaints?

6.5 How often does annulment occur due to lack of attractive proposals that could enhance efficiency and quality?

7. Motivation of private contractors

7.1 How often do your contracts contain precise descriptions and requirements regarding the contracted service?

7.2 How often do your contracts include economic incentives to optimize contract performance?

8. Coordination and collaboration

8.1 How often do your contracts oblige private providers to engage in ongoing dialogue with the public purchaser?

8.2 How often do your contracts oblige private providers to engage in ongoing dialogue with citizens and end users?

9. How often do your contracts contain requirements for specific qualifications and competences?

10. Monitoring of contracts

10.1 How often do you use self-reporting of performance?

10.2 How often do you use spot checks?

10.3 How often do you use joint evaluation procedures?

10.4 How often do you use user satisfaction surveys?

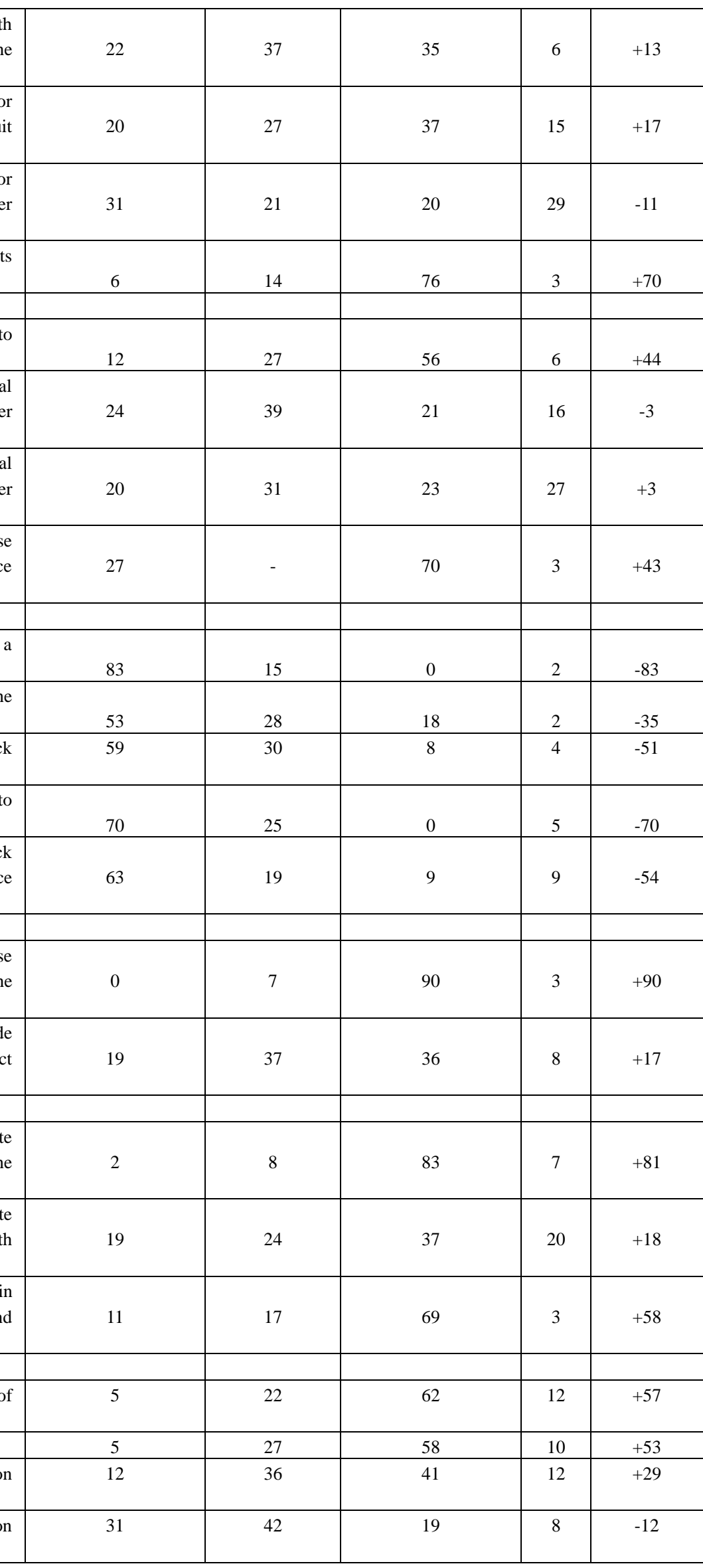




\begin{tabular}{|c|c|c|c|c|c|}
\hline $\begin{array}{l}10.5 \text { To what extent do you think that you have } \\
\text { sufficient knowledge and competence to monitor } \\
\text { contracts? }\end{array}$ & 7 & 34 & 51 & 8 & +44 \\
\hline $\begin{array}{l}\text { 10.6 To what extent do you think that you have } \\
\text { sufficient resources to monitor contracts? }\end{array}$ & 30 & 42 & 19 & 8 & -11 \\
\hline $\begin{array}{l}10.7 \text { How often do you engage contractors in a } \\
\text { dialogue in response to repeated contract } \\
\text { violations? }\end{array}$ & 5 & 8 & 84 & 3 & +79 \\
\hline $\begin{array}{l}10.8 \text { How often do you impose sanctions in } \\
\text { response to repeated contract violations? }\end{array}$ & 14 & 31 & 50 & 5 & +36 \\
\hline $\begin{array}{l}10.8 \text { How often do you terminate contracts in } \\
\text { response to repeated contract violations? }\end{array}$ & 41 & 24 & 27 & 8 & -14 \\
\hline \multicolumn{6}{|l|}{ 11. Knowledge sharing } \\
\hline $\begin{array}{l}11.1 \text { How often do you share knowledge about } \\
\text { contracting out with other municipalities? }\end{array}$ & 0 & 6 & 92 & 2 & $\begin{array}{r}+92 \\
\end{array}$ \\
\hline $\begin{array}{l}11.2 \text { How often do your contracts oblige public } \\
\text { and private contractors to exchange experiences? }\end{array}$ & 25 & 20 & 13 & 41 & -12 \\
\hline
\end{tabular}

Looking at the overall picture, three interesting observations can be made. First, Danish municipalities seem to have built a political and institutional framework for handling contracting out. This is unsurprising since contracting out has been on the municipal agenda in Denmark and has steadily grown in size over the past three decades; and Danish municipalities have considerable administrative resources and well-educated public managers. The Danish public sector frequently tops international rankings for good and efficient governance (Boyle, 2006; World Bank, 2015; Transparency International, 2016) and would seem well prepared to tackle the challenges of contracting out.

Second, in terms of actual governing practices, the picture is uneven, and there are challenges both with regard to efforts to create competitive markets and to reduce transaction costs. This observation is critical because market creation and reduction of transactions costs are important in order for contracting out to lead to cost savings. Unfortunately, the lack of municipal data on cost saving and changes in service quality as a result of outsourcing prevents us from testing the causal relationship between governing practices and outcomes.

Third, the broad picture that emerges of Danish municipalities' governing practices reveals that contracting out is generally approached from a classical principal-agent perspective. Yet while the emphasis on contract monitoring and accountability fits well with principal-agent theory, the relatively high prevalence of governing practices focusing on coordination and collaboration, competence requirements and knowledge sharing seems to go against the grain of the same theory. As such, the survey seems to detect mixed governing paradigms that draw on different theoretical sources.

After these general observations, we will now examine the results in greater detail in order to establish what the municipalities are actually doing when it comes to governing contracting out. According to table 1, the survey shows that most municipalities have managed to secure some relatively good political and administrative conditions for reaping the fruits of contracting out. $78 \%$ have a politically agreed policy for contracting out, and $97 \%$ have a specialized administrative unit that supports and guides contracting out. While these high percentages bear witness to a strong political and administrative focus, there is still some room for improvement as $17 \%$ of municipalities lack a policy for public procurement and 
contracting and, therefore, might fail to define clear goals for public outsourcing and to signal the importance of reaching them.

When it comes to local governing practices aiming to create competitive service markets, the percentage balances reveal that dialogue with potential bidders and making joint requests for proposals with other municipalities are the preferred governance tools. $74 \%$ of the municipalities often, very often or always engage in dialogue with potential bidders in order to find ways to increase the number of bidders by adjusting the description of the service and the conditions for contracting. Surprisingly, $22 \%$ of municipalities say that they never, very rarely or rarely enter into a dialogue with the industry organizing the potential bidders, despite the fact that these industry organizations may have a pretty good overview of the local market situation in different areas. There also seems to be room for improvement when it comes to the segmenting or unbundling of services, which is not much used by $20 \%$ of municipalities in the area of technical services and $31 \%$ of municipalities in the area of social services. By contrast, joint requests for proposals with other municipalities appear to be extremely popular and may help to create larger and more attractive markets while lowering the transactions costs for each of the participating municipalities - something that is extremely important for small municipalities with few administrative resources. This finding is interesting since one of the purposes of the municipal merger reform in 2007 was to create larger municipalities with greater capacity for contracting out services. Although the municipal reform seems to have led to the contracting out of some services rather than others (Foged, 2015), the frequent use of joint requests for proposals might indicate that not all municipalities are big enough to handle the contracting out of specialized services.

The percentage difference of $+44 \%$ suggests that municipalities use pre-qualification to a large extent as a way to reduce transaction costs when there is a very large number of bidders. That $56 \%$ of municipalities use pre-qualification is surprisingly high as it is hardly every day that municipalities encounter a public service area with a high number of potential bidders. By contrast, few make use of the mixed model in which part of a service is deliberately kept in house while another part is contracted out. The percentage balance is negative or negligible both for technical and social services. The sparse use of the mixed model can be a real problem for some municipalities, because it may prevent them from insourcing services delivered by private providers that are underperforming and therefore violating their contractual obligations.

The use of public control bids, which enable public purchasers to check whether proposals submitted by private bidders will actually cut costs and improve quality, is seemingly widespread. It is used by $70 \%$ of municipalities. Nevertheless, $27 \%$ of municipalities do not use control bids and, therefore, have no yardstick with which to measure and control bids by private contractors. Presumably, this is due to lack of administrative capacity as it is quite demanding to make control bids. However, in some of the open answers the respondents explain that control bids are only used the first time a service is contracted out and since contracting out is used in most service areas in their municipality, there are no longer any first-time contracts where control bids would have been used. 
Annulment of requests for proposals is important to prevent municipalities from becoming stuck with an underperforming private contractor, but if the process of contracting out services is well prepared, annulment is unlikely to be an issue. As such, it is reassuring that the high negative percentage difference suggests that annulment is indeed very rare. $83 \%$ of municipalities report that they are never, very rarely or rarely forced to annul a request for proposal, and when annulment does happen, the data suggest that the most frequent reason is that the proposals are judged to be too poor to proceed with the outsourcing process. Failure to annul in these circumstances will lead to negative outcomes.

Contract specifications can be used to motivate private contractors who are delivering public services. As many as $90 \%$ of the municipalities report that their service contracts contain precise descriptions of the service to be delivered and clear quality demands. However, when it comes to building economic incentives for optimizing performance into the service contracts, the percentage difference drops from $+90 \%$ to $+17 \%$. This finding can be interpreted in two ways: either the municipalities find it too complicated to design incentive systems that are not easily gamed by the private contractors, or they fear that incentive systems aiming to spur extrinsic motivation will crowd out other, more important forms of motivation such as professional motivation or public service motivation. If the first explanation is correct, there is definitely room for improvement. If the second explanation is correct, then the motivation of private providers has to be achieved by some other means.

Collaboration between a public purchaser and one or more private contractors is an alternative tool for motivating contractors to fulfill their contractual obligations and optimize performance as it facilitates goal alignment and creates joint commitment to public value production. As evidenced by the results in table 1, Danish municipalities use relational contracts to a large extent, which oblige private providers to engage in continuous collaboration with public purchasers with a view to enhancing performance. $83 \%$ of the municipalities say that they often, very often or always include collaborative requirements in their service contracts. However, while collaboration with the public agency with which they have a contract may stimulate private providers' production of value for money, so will an ongoing dialogue with citizens and end users that can tell the contractors about their needs and help them find ways to improve service quality. Unfortunately, there is a big drop in the percentage difference when we move from collaboration with the public purchaser to collaboration with end users. This falls from $81 \%$ to $18 \%$, and one in five of municipalities reports that they never, very rarely or rarely require that private contractors engage in dialogue with the users they are serving. There is significant room for improvement here.

High-performing service contractors must both be motivated and have the skills, competences and knowledge needed to deliver high quality public services at low costs. Therefore, it is important that the contracts contain specific requirements for qualifications and competences. $69 \%$ of the municipalities report that they frequently include such requirements, $17 \%$ that they sometimes do, and only $11 \%$ claim that they rarely, very rarely or never do. Hence, the room for improvement is small, but significant.

Monitoring of the performance of private providers is of the utmost importance, and it is 
alarming to see that close to half of Danish municipalities report that they do not regularly use the various available methods and techniques for monitoring contract performance. Only $62 \%$ of municipalities regularly use self-reporting of performance, and $58 \%$ use spot checks. A more reliable, effective and relationship-building monitoring technique such as joint evaluation is only used regularly by $41 \%$, and user satisfaction surveys that measure service quality in a very direct way are only used regularly by $19 \%$ of municipalities. Lack of knowledge and competences may be part of the explanation as to why they are not monitoring performance more intensively. Only half the municipalities believe that they possess the required monitoring skills to a large extent. The real problem, however, seems to be lack of resources to monitor contracts. Here, the percentage difference becomes negative as only $19 \%$ are positive about having sufficient resources and $30 \%$ are negative about this. Clearly, monitoring is worthless if it does not involve evaluations and enforce sanctions for contract breaches. The survey asks how often repeated contract violations lead to corrective dialogue, sanctions and termination. As we move from dialogue, via sanctions, to contract termination, the percentage difference drops from $+79 \%$ to $+44 \%$ and ends up at $-11 \%$. This sharp decline indicates that dialogue is the preferred response and that sanctions and terminations are not used very often. This finding might reflect the potency of dialogue and soft power as a tool for dealing with contract violations, but it may also reflect the fact that the more public purchasers collaborate with private contractors in order to create trust and alignment, the harder it becomes to use hard power in terms of imposing penalties and terminating the contract. Failing to use hard power when this is required will undoubtedly lower performance, but frequent use of penalties and contract termination may also give rise to generalized distrust between the public purchaser and the private contractors that prevents constructive collaboration.

The final governing practice to consider is knowledge sharing. The performance of contracting out arrangements can be enhanced through knowledge sharing and mutual learning. $92 \%$ of municipalities report that they regularly engage in inter-municipal knowledge sharing in the field of contracting out. While this very high percentage is promising for the ability to learn from other municipalities' good and bad experiences, it is quite unfortunate that the percentage difference drops from $+92 \%$ in the case of inter-municipal knowledge sharing to $-12 \%$ in the case of knowledge sharing between public and private contractors. Knowledge sharing between public and private providers in the mixed service delivery model is crucial for stimulating mutual learning and continuous improvement of service delivery, but this is presumably prevented by competition.

\section{Improving the Institutional Governing Conditions for Contracting out}

The rather naïve belief that the introduction of market steering in the public sector through privatization and contracting out would lead to deregulation and the decline of bureaucratic governing practices has been shattered by reality. Competitive markets for public service delivery are neither emerging spontaneously nor are they completely self-regulating. Markets must be created, sustained and regulation and contractors must be found, tested, motivated, interacted with, monitored, sanctioned and sometimes terminated. The contracting out of public services must be carefully planned, implemented and evaluated and political support 
and organizational resources must be mobilized in the process.

The question that we have aimed to answer through our nation-wide survey is not only what Danish municipalities are doing when governing contracting out, but also whether they do what they should do in terms of governing, organizing and managing the process of contracting out in order to ensure the desired results. The theoretically and empirically grounded conjectures set out in the previous section point to some local governing practices that are expected to be conducive to reaping the fruits of contracting out, and the analysis of the relative presence of these governing practices gives a good indication of whether the municipalities are on the right track or need to adjust their course. Naturally, the local conditions for governing contracting out will tend to vary, calling for different blends of local governing practices. Nevertheless, the conjectures provide an informed guess about what a typical municipality might do to ensure that contracting out leads to positive outcomes.

Table 1 bears witness to considerable variation in the municipalities' attempts to govern contracting out. When benchmarked against the conjectures, there are areas in which Danish municipalities as a whole are doing particularly well:

- Contracting out is anchored in a politically endorsed local policy that provides clear goals and targets and demonstrates political commitment and focus

- Contracting out is supported by special administrative units that provide resources and legal advice

- Dialogue with potential bidders in the pre-contracting phase is widespread

- Joint requests for proposals with other municipalities are frequently used

- Widespread use of pre-qualification when there are many potential bidders

- Poor proposals lead to annulment of requests for proposals

- Clear descriptions of tasks and service demands in contracts are pervasive

- Private providers are contractually obliged to engage in ongoing dialogue with public purchasers

- Basic monitoring techniques such as self-reporting and spot checks are regularly used

- There is adequate knowledge and competences to monitor performance

- Private contractors are involved in dialogue in the case of repeated contract violations

- There is some sanctioning of private contractors in the case of repeated contract violations

- Knowledge sharing among municipalities is widespread

The survey also detected a number of areas in which a significant proportion of the municipalities are not always doing what they should be doing. Hence, there is considerable room for improvement in local governing practices, since some municipalities: 
- Do not have a special administrative unit to support and guide contracting out (17\%)

- Do not engage in regular dialogue with industrial associations (22\%)

- Do not regularly segment or unbundle public services (31\%)

- Do not use mixed model service contracting (24\%/20\%)

- Do not use public control bids (27\%)

- Do not build economic incentives into their contracts (19\%)

- Do not engage in an ongoing dialogue with end users (19\%)

- Do not make use of user satisfaction surveys to monitor performance (31\%)

- Do not regularly terminate contracts in the case of repeated violations (41\%)

- Do not contractually oblige public and private contractors to share knowledge (25\%)

While more contract terminations in the case of repeated violations may not a goal in itself, some of these areas of neglect are certainly and call for prompt action. First, municipalities that do not yet have a special contracting-out unit should establish one, since the legal rules in the field of contracting out are extremely complex and constantly changing and many line organizations lack both the expertise and the administrative resources to ensure that contracting leads to the desired results, unless they are supported by a special outsourcing unit. Second, the segmenting and unbundling of complex services should become standard procedure in all municipalities as it would help to attract bidders and enhance competition. Third, mixed model contracting should be widely applied as it not only lowers transaction costs of monitoring results, but also reduces the problems that local governments may have when private contractors are going out of business and the service task is transferred back to the municipality. If local governments keep the competence to deliver services that have been outsourced, insourcing the latter services becomes less of a problem. Fourth, municipalities that do not use control bids should make sure that there is sufficient expertise and resources to make such control bids, as they prevent ideologically motivated contracting out that does not lower service delivery costs. Last but not least, efforts should be made to encourage private contractors to engage in dialogue with the users they are serving and to regularly measure their satisfaction. At the end of the day, it is only the end users who can evaluate the quality of the contracted services and they are often prevented from expressing their dissatisfaction by leaving the private service provider, or are reluctant to use their exit option if they have one.

In general, the survey shows that the glass is more than half full. However, as we have seen, there is still room for improvement in certain areas. Indeed, about 20-30\% of Danish municipalities may be able to enhance the implementation and results of contracting out by adopting or intensifying the use of particular governing practices, if local political and administrative conditions allow it. Learning provides a key to improvement. Hence, many municipalities could learn how to better govern their outsourcing practices either by reflecting on their own experiences or by engaging in a dialogue with neighboring 
municipalities and advisory bodies. Mid-career training programs focusing on the governing of contracting out might also prove a valuable source of learning and improvement of the current governing practices.

\section{Conclusion}

In response to the dearth of studies on the governing aspects of contracting out, this article reports on findings from a systematic review of the existing research. Supplementing these findings with results from our own pre-study of Danish experiences has enabled us to formulate a number of conjectures about which governing practices are likely to produce positive outcomes in the field of contracting out. Data from a nation-wide survey further enabled us to assess the prevalence of the governing practices described in our conjectures. The overall finding is that although Danish municipalities seem to be doing a lot to ensure positive outcomes of contracting out, there is still considerable room for improvement. The empirical analysis has identified five areas of improvement in governance, organization and management that may help local governments to enhance the impact of outsourcing: formation of a special outsourcing unit, segmenting and unbundling of complex services, systematic use of mix model contracting, capacity building enable control bids, and mandatory dialogue between private contractors and their service users.

The main limitation of our study is that the survey data can only tell us about the empirical prevalence of particular local governing practices. Due to the absence of standardized municipal data on the outcomes of contracting out, attempts to test the causalities implicit in the conjectures will require either comparative case studies of municipalities with different governing practices or experimental studies of municipalities that have recently adopted a new governing practice in the field of contracting out. Both types of study require precise measurement of the dependent variable in terms of the cost and quality of the public services subject to outsourcing, which is notoriously difficult to do but manageable on a small scale. The independent variables measuring the use of particular governance tools, organizational capacities and management strategies may also require further operationalization in order to capture the finer details of variations among municipalities.

If empirical knowledge about what local municipalities are actually doing in terms of governing contracting out is the first step, and testing the impact of particular governing practices on outcomes is the second step, then the third and final step is to develop a theoretical framework for assessing the impact of governance, organization and management on the outcomes of contracting out. Ideally, such a framework should capture the causal pathways between all the relevant governing practices, a broad set of intermediary impact factors, and the outcomes of contracting out in terms of lower costs without quality reduction. It would be worth looking at how different constellations of governing factors produce different effects. If there are enough high quality case studies Qualitative Comparative Analysis can be used to explore this question. It might take a while before such a theoretical framework is developed and tested. In the meantime, we hope that the empirical results presented in this article can help to stimulate debate about how to improve the governing of contracting out at the level of local government. 


\section{Appendix 1}

The primary studies in the systematic review were carried out as part of a previous research project (see Petersen, Hjelmar, Vrangbæk and la Cour, 2011; Petersen, Hjelmar, Vrangbæk and Larsen, 2014) involving a systematic search in 13 databases: Social Science Citation Index, Sociological Abstracts, Social Services Abstracts, Education Resources Information Center, PILOTS Data base, Campbell Library, Cochrane Library, DanBib, Den Danske Forskningsdatabase, Swepub, Libris, CRIStin, BIBSYS ForskDok. The search covered studies in English and Scandinavian languages that focused on contracting out, public procurement, outsourcing, marketization and service contracting in advanced industrialized countries including Europe, North America, the Antipodes, Japan and South Korea, while excluding studies of privatization and public private partnerships, as well studies of outsourcing, from the rest of the world. In order to narrow the search to suit our purpose, we defined some further search categories and added these to the initial search, namely: governance, management, leadership, organization, steering, coordination, transaction costs. We searched for these terms in titles, abstracts and keywords. The new search produced 140 primary studies that were presumably focused on the public governance of contracting out. In order to verify that the studies actually addressed the contracting out of public services to private actors and focused on issues pertaining to public governance, organization and management, we read all the abstracts and removed 61 articles that, for different reasons, failed to meet our criteria, bringing the sample of relevant studies down to 79. A close reading of all articles revealed that less than 14 studies aimed to assess the conditioning effects of public governance, organization and management on the effectiveness of outsourcing in lowering costs and enhancing quality.

\section{References}

Amaral, M., Saussier, S., \& Yvrande-Billon, A. (2009). Auction procedures and competition in public services, Utilities Policy, 17(2), 166-175. https://doi.org/10.1016/j.jup.2008.07.006

Amirkhanyan, A. A., Kim, H. J., \& Lambright, K. T. (2007). Putting the pieces together: A comprehensive framework for understanding the decision to contract out and contractor performance, International Journal of Public Administration, 30(6-7), 699-725. https://doi.org/10.1080/01900690601125286

Bel, G., \& Fageda, X. (2007). Why do governments privatize public services?, Local Government Studies, 33(4), 517-534. https://doi.org/10.1080/03003930701417528

Boyle, R. (2006). Managing public sector productivity, CPMR Discussion Paper Nr. 35, Dublin: Institute for Public Management.

Boyne, G. A. (1998). Bureaucratic theory meets reality: Public choice and service contracting in U.S. local government, Public Administration Review, 58(6), 474-484. https://doi.org/10.2307/977575

Brown, T. L., \& Potoski, M. (2004). Managing the public service market, Public Administration Review, 64(6), 656-668. https://doi.org/10.1111/j.1540-6210.2004.00413.x 


\section{Macrothink}

Journal of Public Administration and Governance

ISSN 2161-7104

2018, Vol. 8, No. 3

Brown, T. L., Potoski, M., \& Slyke, D. M. (2006). Managing public service contracts, Public Administration Review, 66(3), 323-331. https://doi.org/10.1111/j.1540-6210.2006.00590.x

Constantino, N., Dotoli, M., Falagario, M., \& Sciancalepore, F. (2012). Balancing the additional costs of purchasing and the vendor set dimension to reduce public procurement costs, Journal of Purchasing and Supply Management, 18(3), 189-198. https://doi.org/10.1016/j.pursup.2012.08.001

Desrieux, C., Chong, E., \& Saussier, S. (2013). Putting all one's eggs in one basket: Relational contracts and the management of local public services, Journal of Economic Behavior and Organization, 89(2), 167-186. https://doi.org/10.1016/j.jebo.2012.03.001

Domberger, S., \& Jensen, P. H. (1997). Contracting out by the public sector, Oxford Review of Economic Policy, 13(4), 67-78. https://doi.org/10.1093/oxrep/13.4.67

Donahue, J. D. (1989). The Privatization Decision: Public Ends, Private Means, New York: Basic Books.

Girth, A. M., Hefetz, A., Johnston, J. M., \& Warner, M. E. (2012), Outsourcing public service delivery: Management responses in non-competitive markets, Public Administration Review, 72(6), 887-900. https://doi.org/10.1111/j.1540-6210.2012.02596.x

Greenwood, D. T. (2014). The decision to contract out: Understanding the full economic and social impacts, report from Colorado Center for Policy Studies. URL: http://www.uccs.edu/Documents/ccps/2014/

contracts-broaderimpacts-greenwood-march-2014-REVISED-AND-FINAL.pdf

Greve, C. (2007), Contracting for Public Services, London: Routledge.

Hefetz, A., \& Warner, M. E. (2011). Contracting or public delivery, Journal of Public Administration Research and Theory, 22, 289-317. https://doi.org/10.1093/jopart/mur006

Kelman, S. J. (2002). Contracting', in L. M. Salamon (Ed.) The Tools of Government, New York: Oxford University Press, 282-318.

Kettl, D. F. (1993), Sharing Power: Public Governance and Private Markets, Washington, DC: The Brooking Institution.

Klein, B., Crawford, R. G., \& Alchian, A. A. (1978). Vertical integration, appropriable rents, and the competitive contracting process, The Journal of Law and Economics, 21(2), 297-326. https://doi.org/10.1086/466922

Koning, P., \& Heinrich, C. J. (2013). Cream-skimming, parking and other intended and unintended effects of high powered performance based contracts, Journal of Policy Analysis and Management, 32(3), 461-483. https://doi.org/10.1002/pam.21695

Lenferink, S., Tillema, T., \& Arts, J. (2013). Public-private interaction in contracting, Public Administration, 91(4), 928-946. https://doi.org/10.1111/padm.12033

Lindholst, A. C. (2009), Contracting-out in urban green-space management, Urban Forestry 
and Urban Greening, 8(4), 257-268. https://doi.org/10.1016/j.ufug.2009.07.002

Lindholst, A. C., \& Bogetoft, P. (2011). Managerial challenges in public service contracting, Public Administration, 89(3), 1036-1062. https://doi.org/10.1111/j.1467-9299.2010.01873.x

Ohemeng, F. L. K., \& Grant, J. K. (2014), Neither public nor private: The efficacy of mixed model public service delivery in two Canadian municipalities, Canadian Public Administration, 57(4), 548-572. https://doi.org/10.1111/capa.12090

Osborne, D., \& Gaebler, T. (1993), Reinventing Government, Reading: Addison-Wesley.

Pallesen, T. (2004). A political perspective on contracting out, Governance, 17(4), 573-587. https://doi.org/10.1111/j.0952-1895.2004.00258.x

Peat, B., \& Costley, D. L. (2001). Effective contracting of social services, Nonprofit Management and Leadership, 12(1), 55-74. https://doi.org/10.1002/nml.12105

Petersen, O. H., \& Hjelmar, U. (2014). Marketization of welfare services in Scandinavia, Scandinavian Journal of Public Administration, 17(4), 3-20.

Petersen, O. H., Hjelmar, U., \& Vrangbæk, K. (2015). Is contracting out of public services still the great panacea?, paper presented at the ICPP konferencen in Milan, 1-4 July.

Petersen, O. H., Hjelmar, U., Vrangbæk, K., \& la Cour, L. (2011), Effekter ved udlicitering af offentlige opgaver: En forskningsbaseret gennemgang af danske og internationale unders $\phi$ gelser fra 2000-2011, Copenhagen: AKF.

Petersen, O. H., Hjelmar, U., Vrangbæk, K., \& Larsen, P. T. (2014), Effekter ved udlicitering af offentlige opgaver: En forskningsoversigt over danske og internationale studier fra 2011-2014, Copenhagen: KORA.

Romzek, B. S., \& Johnston, J. M. (1999). Reforming Medicaid through contracting, Journal of Public Administration Research and Theory, 9(1), 107-139. https://doi.org/10.1093/oxfordjournals.jpart.a024402

Romzek, B. S., \& Johnston, J. M. (2005). State social service contracting, Public Administration Review, 65(4), 436-449. https://doi.org/10.1111/j.1540-6210.2005.00470.x

Savas, E. S (1987), Privatization: The Key to Better Government, Chatham: Chatham House Publishers.

Seidenstat, P. (1999), Contracting Out Government Services, Westport: Praeger.

Transparency International (2016). Corruption Perceptions Index 2014. URL: https://www.transparency.org/cpi2014/results

Udbudsportalen (2011), Vejledning: Udbud trin for trin, København: Udbudsportalen.

Walls, M. (2005). How local governments structure contracts with private firms, Public Works Management \& Policy, 9(3), 206-222. https://doi.org/10.1177/1087724X04271849

Warner, M. E., \& Hefetz, A. (2008). Managing markets for public service, Public 


\section{Macrothink}

Journal of Public Administration and Governance ISSN 2161-7104 2018, Vol. 8, No. 3

Administration Review, 68(1), 155-166. https://doi.org/10.1111/j.1540-6210.2007.00845.x

Williamson, O. E. (1985). The Economic Institutions of Capitalism, New York: Free Press.

Williamson, O. E. (1991). Comparative economic organization, Administration Science Quarterly, 36(2), 269-296. https://doi.org/10.2307/2393356

World Bank. (2015). Worldwide Governance Indicators: Country report for Denmark, 1996-2014, Washington, DC: World Bank.

http://info.worldbank.org/governance/wgi/pdf/c63.pdf

\section{Copyright Disclaimer}

Copyright for this article is retained by the author(s), with first publication rights granted to the journal.

This is an open-access article distributed under the terms and conditions of the Creative Commons Attribution license (http://creativecommons.org/licenses/by/4.0/). 